\begin{tabular}{|c|l|}
\hline Title & Effect of lycopene and beta carotene on peroxynitrite mediated cellular modifications. \\
\hline Author(s) & $\begin{array}{l}\text { Muzandu, Kaampwe; Ishizuka, Mayumi; Sakamoto, Kentaro Q.; Shaban, Zein; El Bohi, Khlood; Kazusaka, A kio; } \\
\text { Fujita, Shoichi }\end{array}$ \\
\hline Citation & $\begin{array}{l}\text { Toxicology and A pplied Pharmacology, 215(3), 330-340 } \\
\text { https://doi.org/10.1016/.taap.2006.03.006 }\end{array}$ \\
\hline Issue Date & 2006-09-15 \\
\hline Doc URL & http://hdl.handle.net/2115/14760 \\
\hline Type & article (author version) \\
\hline File Information & TAP215-3.pdf \\
\hline
\end{tabular}

Instructions for use 
TITLE OF THE PAPER:

EFFECT OF LYCOPENE AND BETA-CAROTENE ON PEROXYNITRITE-MEDIATED CELLULAR MODIFICATIONS

AUTHORS:

KAAMPWE MUZANDU, MAYUMI ISHIZUKA, KENTARO Q SAKAMOTO, ZEIN SHABAN, KHLOOD EL BOHI, AKIO KAZUSAKA, SHOICHI FUJITA ${ }^{1}$

\section{AFFILIATION OF AUTHORS:}

Laboratory of Toxicology, Department of Environmental Veterinary Sciences, Graduate School of Veterinary Medicine, Hokkaido University, Sapporo 060-0818, Japan

\section{RUNNING TITLE:}

Carotenoids protect cells against peroxynitrite

\section{${ }^{1}$ CORRESPONDING AUTHOR:}

Professor Shoichi Fujita

Laboratory of Toxicology, Department of Environmental Veterinary Sciences, Graduate School of Veterinary Medicine, Hokkaido University, N18, W9, Kita-Ku, Sapporo 060-0818, Japan;

TEL: 81-11-706-6948; Fax: 81-11-706-5105; E-mail: fujita@vetmed.hokudai.ac.jp 


\begin{abstract}
Peroxynitrite formed by the reaction of superoxide and nitric oxide is a highly reactive species with a role in various pathological processes such as cancer, chronic inflammation, and cardiovascular and neurological diseases. In the present study, the effect of the carotenoids, lycopene and $\beta$-carotene, on peroxynitrite-mediated modifications in plasmid DNA as well as cellular DNA and proteins were investigated. In pUC18 plasmid DNA, these carotenoids strongly inhibited DNA strand breaks caused by peroxynitrite generated from 3-morpholinosydnonimine (SIN-1). SIN-1 was also used to determine effects on DNA damage and protein tyrosine nitration in Chinese hamster lung fibroblasts. SIN-1 dose-dependently increased nitration of proteins in cells above basal levels as determined by western blotting. This nitration was inhibited in the presence of the uric acid as well as lycopene. Physiological concentrations (0.31-10 $\mu \mathrm{M})$ of lycopene and $\beta$-carotene also had protective effects on DNA damage, as measured by the comet assay. Lycopene significantly reduced DNA damage particularly, in the median range of concentrations (2.5 $\mu \mathrm{M})$. The protective effects of lycopene and $\beta$-carotene could be due to their scavenging of reactive oxygen (ROS) and/or nitrogen species (RNS) as they reduce the amount of intracellular ROS/RNS produced following treatment with SIN-1 by as much as 47.5 and $42.4 \%$, respectively. The results obtained in this study suggest that carotenoids may alleviate some of the deleterious effects of peroxynitrite and possibly other reactive nitrogen species as well in vivo.
\end{abstract}

Keywords: DNA damage, protein tyrosine nitration, lycopene, $\beta$-carotene, peroxynitrite. 


\section{Introduction}

Increased consumption of fruits and vegetables is associated with a lower risk disease, including cancer, and cardiovascular and neurological pathologies (Ames et al., 1993). Research has been focused on known antioxidants in foods that may confer these beneficial effects, such as polyphenols, vitamins, and carotenoids. Of particular interest in this paper, are the carotenoids, lycopene and $\beta$-carotene and their effects on peroxynitrite-mediated protein and DNA modifications.

Peroxynitrite ( $\mathrm{ONOO} / \mathrm{ONOOH})$, a potent oxidising and nitrating species (Beckman, 1996, Koppenol et al., 1992), is the product of the near diffusion-limited reaction of nitric oxide (NO) and superoxide anion $\left(\mathrm{O}_{2}{ }^{-}\right.$). The rate constant for this reaction is $6.7 \times 10^{9} \mathrm{M}^{-1} \mathrm{~s}^{-1}$ (Burney et al., 1999). Peroxynitrite is relatively long-lived with a half-life of approximately $1 \mathrm{~s}$ under physiological conditions. At physiological $\mathrm{pH}$ and temperature, peroxynitrite will, following protonation, exist as $20 \%$ peroxynitrous acid (ONOOH, $\left.\mathrm{p} K_{\mathrm{a}} 6.8\right)$ (Beckman, 1996), which in turn decomposes to yield multiple toxic products with reactivities similar to those of the nitryl cation $\left(\mathrm{NO}_{2}^{+}\right)$, nitrogen dioxide $\left(\cdot \mathrm{NO}_{2}\right)$ and hydroxyl radical $(\cdot \mathrm{OH})$. An important biological reaction of peroxynitrite is that with $\mathrm{CO}_{2}$ to yield nitrosoperoxycarbonate $\left(\mathrm{ONOO} \mathrm{CO}_{2}{ }^{-}\right)$(Dedon and Tannenbaum, 2004), which also eventually decomposes to yield $\mathrm{NO}_{3}^{-}$. The $\mathrm{CO}_{3}^{-}$and $\bullet \mathrm{NO}_{2}$ radicals may be intermediates in this decomposition process.

Reactions of peroxynitrite with biomolecules are complex and numerous and include oxidations, such as DNA damage leading to sugar and base modifications, mutations, and also single- and double-strand breaks (Burney et al., 1999, Dedon and Tannenbaum, 2004). Peroxynitrite, may also nitrate DNA, though the extent and importance of this reaction is unclear. Other than DNA, peroxynitrite also produces oxidative and nitrosative damage to lipids and proteins. Protein tyrosine nitration, the addition of a nitro group $\left(-\mathrm{NO}_{2}\right)$ onto one of the two equivalent ortho carbons of the aromatic ring of tyrosine residues (Gow et al., 2004), has been associated with a number of pathological states (Pietraforte et al., 2003).

Lycopene and $\beta$-carotene are potent quenchers of singlet oxygen and peroxyl radicals. There is 
emerging evidence for their role in scavenging reactive nitrogen species (RNS). Beta-carotene is a strong scavenger of RNS in solution, including nitrogen dioxide, and peroxynitrite (Kikugawa et al., 1997). Lycopene and $\beta$-carotene have also been shown to be consumed in the process of scavenging peroxynitrite in low density lipoproteins (Panasenko et al., 2000, Pannala et al., 1998). While a number of studies have reported protective effects of carotenoids against DNA damage by various toxins in cell culture (Glei et al., 2002, Matos et al., 2000, Lowe et al., 1999, Weitberg et al., 1985), some have found no protective effects (Woods et al., 1999, and Yeh et al., 2001). However, there are few reports on interactions of carotenoids with peroxynitrite or its derived species and effect on DNA damage and/or protein tyrosine nitration.

The goal of the present study was to assess the effectiveness of intracellular carotenoids against some biological effects of peroxynitrite, such as DNA damage, as assessed with the comet assay (single-cell gel electrophoresis), and protein tyrosine nitration, determined by western blotting. SIN-1 (3-morpholinosydnonimine) was used as a model compound for the continuous release of nitric oxide and superoxide and hence continuous formation of peroxynitrite as might occur in an in vivo setting. In some cases authentic peroxynitrite was also used.

\section{Materials and methods}

\section{Chemicals}

SIN-1 (a peroxynitrite generator) was obtained from Dojindo Laboratories (Kumamoto, Japan). Dihydrorhodamine 123 was from Sigma Aldrich Chemicals Ltd. (St. Louis, USA). Lycopene, $\beta$-carotene and tetrahydrofuran (THF) stabilized with $\sim 0.03 \%$ 2,6-di-t-butyl-4-methyl-phenol (BHT) were from Wako Pure Chemicals Ltd. (Osaka, Japan). Plasmid DNA pUC18 was obtained from Wako Pure Chemicals Ltd. (Osaka, Japan) and subsequently prepared as previously described (Muzandu et al., 2005a).

Authentic peroxynitrite was synthesized as described by Radi et al. (1991) with some modifications. Briefly, equal volumes of $0.6 \mathrm{M}$ sodium nitrite and acidified hydrogen peroxide (0.7 $\mathrm{M}$ in $0.6 \mathrm{M} \mathrm{HCl}$ ) were drawn into two separate syringes, analogous to a stop-flow set up. Both solutions were simultaneously injected into a beaker with continuous stirring at $4{ }^{\circ} \mathrm{C}$ and the product of the reaction was immediately stabilized with an equal volume of $1.5 \mathrm{M} \mathrm{NaOH}$. Excess 
$\mathrm{H}_{2} \mathrm{O}_{2}$ was removed by treating this solution with excess manganese dioxide $(100 \mathrm{mg} / \mathrm{ml})$. The solution was filtered and frozen at $-20{ }^{\circ} \mathrm{C}$ for up to one week. The peroxynitrite-containing top yellow layer formed by freeze-fractionation was collected. Residual $\mathrm{H}_{2} \mathrm{O}_{2}$ was quantified spectrophotometrically as described elsewhere (Josephy et al., 1982) and determined to be approximately $0.7 \%$ per mole of peroxynitrite. The concentration of peroxynitrite was quantified spectrophotometrically in $1.5 \mathrm{M} \mathrm{NaOH}$ at $302 \mathrm{~nm}\left(\varepsilon=1670 \mathrm{M}^{-1} \mathrm{~cm}^{-1}\right)$. Solutions were stored in aliquots at $-80{ }^{\circ} \mathrm{C}$.

Stock carotenoid solutions were dissolved in THF and kept at $-80{ }^{\circ} \mathrm{C}$. Working solutions were prepared fresh on the day of an experiment. Exact concentrations were determined spectrophotometrically using established extinction coefficients (Schierle et al., 1997). In the cell culture experiments, a small amount of stock solution was added to the medium, stirred vigorously and then filtered with a $0.45 \mu \mathrm{m}$ millipore filter (Billerica, MA, USA). Final concentrations of the carotenoids in the media were measured by spectrophotometry after extraction in $n$-hexane. All procedures were performed under dim light. Decomposed SIN-1, THF or $\mathrm{NaOH}$ alone had no effect on any of the parameters tested.

\section{Induction of strand breaks in plasmid DNA}

Agarose gel electrophoretic patterns of plasmid pUC18 DNA (2686 bp) were used to measure single strand breaks (ssb). The method is as described by Li and Trush (1993) with some modifications. Briefly, $0.1 \mu$ g of DNA was incubated with various chemicals in KPB, pH 7.4 at $37^{\circ} \mathrm{C}$ for $30 \mathrm{~min}$ (final volume $10 \mu \mathrm{l}$ ). The carotenoids, dissolved in $1 \%$ solutions in THF, were added to the reaction mixture just before SIN-1. The final concentration of THF was $0.1 \%$. SIN-1 was dissolved in $10 \mathrm{mM} \mathrm{NaOH}$ and used at a final concentration of $100 \mu \mathrm{M}$. The reaction was terminated by the addition of $2 \mu \mathrm{l}$ of electrophoresis loading buffer. Immediately after exposure, the DNA was loaded onto a $1 \%$ agarose gel prepared in Tris Acetate/ ethylenediamine tetra acetic acid (EDTA) buffer (40 mM Tris, 20 mM sodium acetate and 2 mM EDTA, pH 7.0) and gel electrophoresis was carried out for 2 hours at $8.5 \mathrm{~V} / \mathrm{cm}$ in a horizontal gel electrophoresis apparatus. The gels, pre-stained with $0.5 \mu \mathrm{g} / \mathrm{ml}$ ethidium bromide, were exposed to UV light. Pictures were taken and scanned, and the DNA strand breaks were measured by the conversion of supercoiled pUC18 double-stranded DNA to open circular and/or linear forms by densitometry. 
The number of single strand breaks was calculated as previously described (Epe and Hegler, 1994).

\section{Cell culture}

Experiments were carried out using a Chinese hamster lung fibroblast cell line (V79 cells)(RIKEN BioResource Center, Tsukuba, Japan). Cells were grown in Eagle’s Minimum Essential Medium (MEM) supplemented with $0.292 \mathrm{~g} / \mathrm{l}$ L-glutamine and $26.2 \mathrm{mM}$ sodium bicarbonate, 10\% Fetal Calf Serum (FCS) and antibiotics at $37^{\circ} \mathrm{C}$ in $5 \% \mathrm{CO}_{2}$ in air.

\section{Cellular DNA damage}

Cells were seeded in 35-mm dishes and allowed to attach overnight. They were treated with lycopene, $\beta$-carotene or THF for $24 \mathrm{~h}$. The media were replaced, after washing with PBS (phosphate-buffered saline), with air-saturated media. Cells were then treated with SIN-1 or $\mathrm{NaOH}$ (vehicle) for $1 \mathrm{~h}$. Cell viability after exposure to various treatments was carried out by the trypan blue dye exclusion method and also by a cell counting kit (CCK-8; Dojindo Laboratories, Kumamoto, Japan). Damage to DNA in V79 cells was assessed with the comet assay according to the method of Singh et al. (1988) with some modifications (Collins and Dusinska, 2002). Briefly, slides were coated with a first layer of $1 \%$ normal agarose. Approximately 20,000 cells were suspended in $50 \mu \mathrm{l}$ 0.5\% low melting point agarose and layered onto the slides, which were then immediately covered with cover slips. After agarose solidification at $4^{\circ} \mathrm{C}$ for $5 \mathrm{~min}$, cover slips were removed and slides were immersed for 1 hour at $4^{\circ} \mathrm{C}$ in fresh lysis solution $(2.5 \mathrm{M} \mathrm{NaCl}, 100$ mM Na${ }_{2}$ EDTA, $10 \mathrm{mM}$ Tris, $\mathrm{pH}$ 10) containing 1\% Triton $\mathrm{X}-100$. The slides were equilibrated in alkaline solution ( $1 \mathrm{mM} \mathrm{Na} \mathrm{F}_{2}$ EDTA, $300 \mathrm{mM} \mathrm{NaOH}, \mathrm{pH}>13$ ) for $40 \mathrm{~min}$. Electrophoresis was carried out for $30 \mathrm{~min}$ at $1 \mathrm{~V} / \mathrm{cm}$. Afterwards, slides were neutralized by washing them three times with 0.4 M Tris buffer ( $\mathrm{pH} 7.5$ ) every 5 min. Slides were stained with ethidium bromide ( $2 \mu \mathrm{g} / \mathrm{ml})$. Images were scored using a fluorescent microscope (Olympus BX50 equipped with a 520-550 nm excitation filter). Based on the extent of strand breakage, cells were classified according to their tail length in five categories, ranging from 0 (no visible tail) to 4 (still a detectable head of the comet but most of the DNA in the tail).

Each cell (or comet) was assigned a value according to the class it belonged to, so that an overall score was derived for each treatment ranging from 0 to 400 arbitrary units. The following formula (Liu et al., 2002) was used to calculate scores in which $N$ is the number of cells in each category 
(e.g. $N_{4}$ is the number of cells in category 4 ).

$$
\text { Score }=\left(0 \times N_{0}+1 \times N_{1}+2 \times N_{2}+3 \times N_{3}+4 \times N_{4}\right) \times 100 /\left(N_{0}+N_{1}+N_{2}+N_{3}+N_{4}\right)
$$

\section{Protein tyrosine nitration}

Detection of nitrated proteins in cells was done by western blotting. Cells were solubilized in ice-cold cell lysing buffer, comprising 50 mM Tris-HCl (pH 7.4), 1 mM EDTA, 150 mM NaCl, 0.25\% sodium deoxycholate, $1 \mathrm{mM} \mathrm{NaF}, 1 \mathrm{mM} \mathrm{Na} \mathrm{VO}_{4}, 1 \%$ NP-40, 1 mM PMSF, $1 \mu \mathrm{g} / \mathrm{ml}$ pepstatin, aprotinin and leupeptin. The samples were gently rocked on an orbital shaker in the cold room for 15 minutes and then clarified by centrifugation at $14,000 \mathrm{x}$ g for $15 \mathrm{~min}$ at $4^{\circ} \mathrm{C}$. The supernatants were collected and their protein concentrations were determined, for normalization of protein levels, by the method of Lowry et al. (1951). Equal amounts of protein were mixed 1:1 with sample buffer, comprising 5\% glycerol, 1\% SDS, 2.5\% ß-mercaptoethanol (v/v), 0.002\% bromophenol blue, and $31 \mathrm{mM}$ Tris- $\mathrm{HCl}(\mathrm{pH}$ 6.8). The samples were then boiled for 5 min and clarified by brief centrifugation. Subsequently, samples were loaded onto a $12 \%$ SDS-polyacrylamide gel electrophoresis (PAGE) gel. Proteins were then transferred to nitrocellulose membranes, and stained with Ponseau S, to verify equivalent transfer of samples. Membranes were blocked for $1 \mathrm{~h}$ at room temperature with phosphate-buffered saline containing $5 \%$ skimmed milk. Thereafter, the membranes were incubated overnight at $4^{\circ} \mathrm{C}$ with mouse monoclonal anti-nitrotyrosine (Chemicon International, CA, USA) at a dilution of 1:500. The membranes were washed three times (5 min each time) with phosphate-buffered saline and incubated for $2 \mathrm{~h}$ at room temperature with a goat anti-mouse horseradish peroxidase-conjugated IgG antibody (1:5,000 dilution) (Chemicon International, CA, USA). Immunoreactivity was determined using the enhanced chemiluminescence system (ECL-Plus) (Amersham Life Science, Cleveland, $\mathrm{OH}, \mathrm{USA}$ ). The blots were stripped and re-probed with anti-actin antibodies to correct for differences in protein loading.

\section{Amino acid sequence analysis}

SDS-PAGE and western blotting was carried out as described above except that proteins were blotted onto PVDF membranes from which bands of interest were cut out and submitted for amino acid sequencing. The N-terminal sequence of the protein on PVDF membrane was determined using a Procise 492 Protein Sequencer (PerkinElmer Life Sciences). 


\section{Oxidation of dihydrorhodamine}

The formation of peroxynitrite from the decomposition of SIN-1 in potassium phosphate buffer and MEM was determined by the oxidation of dihydrorhodamine 123 to rhodamine 123 (Fig. 5). The reaction mixture comprised $50 \mu \mathrm{M}$ SIN-1 in either MEM or $0.1 \mathrm{M} \mathrm{KPB}, \mathrm{pH} 7.4$ at $37^{\circ} \mathrm{C}$ containing $500 \mu \mathrm{M}$ dihydrorhodamine 123. To determine the amount of oxidation due to hydrogen peroxide catalase was used. Fluorescence was recorded as described below. The peroxynitrite-dependent oxidation of dihydrorhodamine 123 to rhodamine 123 in cells (Fig. 6 and 7) was measured as described previously (Muzandu et al, 2005b), with some modifications. Briefly, cells cultured in 24-well dishes were incubated with cell culture media containing $5 \mu \mathrm{M}$ dihydrorhodamine 123 for $2 \mathrm{~h}$ at $37^{\circ} \mathrm{C}$. After washing twice with phosphate buffered saline, cells were exposed to SIN-1 (Fig. 6) in air-saturated cell culture media after which fluorescence was recorded using fluorescence plate reader with excitation and emission wavelengths of 485 and 535 nm, respectively. In experiments with carotenoids (Fig. 7), cells were pre-treated with lycopene or $\beta$-carotene at 0.1-5 $\mu \mathrm{M}$ for $24 \mathrm{~h}$, washed with phosphate buffered saline, and loaded with dihydrorhodamine 123 as above. They were then exposed to $1 \mathrm{mM} \mathrm{SIN-1}$ for $1 \mathrm{~h}$ in an incubator at $37^{\circ} \mathrm{C}$ after which fluorescence was recorded. Background fluorescence was subtracted.

\section{Statistical analysis}

Statistical analysis was performed by two-way ANOVAs followed by Tukey's test or Student's t-test with Bonferroni correction as post hoc analysis. We also used Student's t-test to compare paired samples, and also performed Tukey's test for multiple comparisons. $P \leq 0.05$ was considered to be significant.

\section{Results}

The results presented in Table 1-1 show the effects of lycopene and $\beta$-carotene on DNA single-strand breaks produced by peroxynitrite generated from the peroxynitrite donor, SIN-1. We analyzed data using two-way ANOVA followed by post-hoc Tukey's test or Student's t-test with Bonferroni correction. Background levels of DNA damage (THF only-treated DNA), 0.15-0.39 single strand breaks (SSB)/ $10^{4}$ bp DNA, were subtracted. Strand breaks in DNA were partially inhibited by both carotenoids. Both carotenoids were effective in inhibiting strand breaks and 
exhibited stronger efficacy with increasing dose (two-way ANOVA, carotenoids: $F=4.89, P=0.03$, concentrations: $F=66.06, P<0.0001)$. Figure 1 depicts representative agarose gel pictures of single strand breaks elicited by $0-100 \mu \mathrm{M}$ authentic peroxynitrite (Fig. 1a) and SIN-1 (Fig. 1b) and the effect of lycopene (Fig. 1c) and $\beta$-carotene (Fig. 1d) on these strand breaks. Both peroxynitrite and SIN-1 treatment of DNA elicited dose-dependent increase in damage. Though SIN-1 is commonly used to generate a continuous flux of $\mathrm{O}_{2}{ }^{-}$and $\mathrm{NO}$, and thus peroxynitrite, its decomposition in various buffers and media leads to the formation of $\mathrm{H}_{2} \mathrm{O}_{2}$ (Lomonosova et al., 1998; Kirsch et al., 1999), which may contribute to DNA damage. Addition of SOD, catalase or both had no effect on DNA strand breaks caused by peroxynitrite (Fig. 1a). In the case of SIN-1 (Fig. 1b), strand breaks were inhibited by SOD ( 97\% inhibition) and a combination of both SOD and catalase ( 100 \% inhibition). Catalase alone had no effect on these strand breaks. A similar approach was employed in experiments done using mammalian cells as explained below.

The toxicity of authentic peroxynitite, SIN-1 or carotenoids to V79 cells was determined by the trypan blue dye assay for membrane integrity and statistically analyzed by two-way ANOVA and post hoc test, Tukey's or Student's t-test with Bonferroni correction. In some cases, metabolic assay, CCK-8, for cell viability was also employed (Table 2-1). Cells incubated with SIN-1 for $1 \mathrm{~h}$ at $37^{\circ} \mathrm{C}$ showed no loss in viability and we detected no difference (Table 2-1, 2-2, P>0.05). Authentic peroxynitrite also produced no loss in viability with respect to membrane integrity $(P>0.05$ by ANOVA). However, there was indication of some cytotoxicity at higher concentrations with the metabolic assay (Table 2-1, reagents $F=12.65 ; P=0.021$, concentrations $F=3.00 ; P=0.001)$. Lycopene or $\beta$-carotene at concentrations $0.1-10 \mu \mathrm{M}$ did not reduce viability of V79 cells after incubation for $24 \mathrm{~h}$ as determined by the trypan blue dye assay for membrane integrity (Table $2-3, P>0.05$ by ANOVA).

Both SIN-1 and authentic peroxynitrite increased the level of DNA damage in cells with time as shown in Fig. 2a (two-way ANOVA, time $F=83.48 ; P<0.0001$, reagents $F=771.49 ; P<0.0001$, time*reagents $F=24.06$; $P<0.0001$ ). The level of damage reached a peak at 30 and $45 \mathrm{~min}$ for peroxynitrite and SIN-1, respectively, after which it was maintained for at least 90 min. Peroxynitrite produced a higher level of DNA damage in these cells compared to SIN-1 and vehicle only ( $P \leq 0.05$ by post hoc Tukey's tests). When cells were exposed to different concentrations of SIN-1 or authentic peroxynitrite for $1 \mathrm{~h}$, the damage to DNA was 
dose-dependent reaching a peak at $500 \mu \mathrm{M}$ (Fig. 2b, two-way ANOVA, reagent $F=159.64$; $P<0.0001$, concentrations $F=31.78 ; P<0.0001$, reagent*concentration $F=4.89 ; P=0.0002$ ). Differences revealed by common letters in figure $2 \mathrm{~b}$ were evaluated by post hoc Tukey's test $(P \leq 0.05)$. Superoxide dismutase added prior to exposure of cells to SIN-1 or peroxynitrite inhibited DNA damage due to SIN-1 by 75\%. Catalase and a combination of SOD and catalase inhibited DNA damage by approximately $9 \%$ and $86 \%$, respectively (two-way ANOVA, SOD $F=82.57 ; P \leq 0.0001$, catalase $F=1.51, P=0.25$ ). These antioxidants had no effect on DNA damage caused by authentic peroxynitrite ( $P>0.05$ by two-way ANOVA).

The modulatory role of intracellular carotenoids on DNA damage was also evaluated in cells by Tukey's test (Fig. 3). Results with lycopene treatment (Fig. 3a) revealed potent inhibition of SIN-1-induced DNA damage as measured by the comet assay. Inhibition was up to $4.3 \%$ (at 1.25 $\mu \mathrm{M}$ ) of the SIN-1-only treated cells with no differences within the different lycopene concentrations. Beta-carotene treatment (Fig. 3b) produced similar results (inhibition: 21.7 - 43 \%).

Figure 4 shows generalized protein nitration in V79 cells. These cells demonstrated some background, endogenously nitrated proteins. SIN-1 increased the level of nitration in proteins above the vehicle ( $\mathrm{NaOH}$-treated cells)(Fig. 4a). In earlier preliminary experiments, neither of the vehicles used, i.e. $\mathrm{NaOH}$ and THF, induced nitration in proteins. Furthermore, these vehicles did not inhibit SIN-1-induced protein nitration. As shown in Fig. 4b, lycopene attenuated nitration by SIN-1. This nitration was also inhibitable by uric acid. In fact, uric acid also mediated a remarkable reduction in the intensity of the band at approximately $40 \mathrm{kDa}$. Superoxide dismutase and $\beta$-carotene tended to reduce the nitration of proteins by SIN-1 ( $P>0.05$ by Tukey's test, $P=0.067$ and 0.066 , respectively by Student's t-test with Bonferroni correction). Proteins nitrated in V79 cells had molecular weights just above 62 and $83 \mathrm{kDa}$. Further analysis of these particular proteins revealed that the band nitrated just above $62 \mathrm{kDa}$ had the amino acid sequence AEVKKPVEAAAWGTREKLSW, which corresponds to GP50 protein. Its migration at $>62 \mathrm{kDa}$ may be due to other protein modifications such as glycosylation. The band occurring just above 83 kDa had the amino acid sequence NFTVDQIRAIMDKKAN. This protein corresponds to ef-2 (elongation factor 2), a $97 \mathrm{KDa}$ protein. At present, it is not known exactly how nitration may affect the function(s) of these proteins. 
As mentioned earlier, SIN-1 is commonly used to generate ultimately peroxynitrite. However, the extent of formation of peroxynitrite from SIN-1 may differ depending on the physiological buffers or cell culture media used. Furthermore, hydrogen peroxide, which is known to damage DNA and oxidize dihydrorhodamine 123, may be a significant by-product during SIN-1 decomposition. In this study, potassium phosphate buffer (KPB) and Eagle’s Minimum Essential Medium (MEM) were used and the yield of peroxynitrite from SIN-1 was investigated. The extent of oxidation of DHR 123 due to hydrogen peroxide was also investigated. As observed in Fig. 5a, the rate of formation of rhodamine, which was linear up to $30 \mathrm{~min}$, differs in the different buffers or media, being higher in KPB. From the linear portion of the curves, the slopes indicate rates of formation of peroxynitrite of 1.54 and $0.64 \mu \mathrm{M} / \mathrm{min}$ in KPB and MEM respectively, taking into account that 1 mole of peroxynitrite yields 0.5 mole of rhodamine (Kooy et al., 1994). Fluorescence reached a plateau within $90 \mathrm{~min}$. Nonlinear regression analysis gave half-lives of peroxynitrite of 27.8 and 31.9 min in KPB and MEM, respectively. Addition of catalase to eliminate any hydrogen peroxide formed decreased the amount of rhodamine formed from SIN-1 in MEM by $27.3 \%$ after allowing $4 \mathrm{~h}$ for oxidation of DHR123 (Fig. 5b, $P \leq 0.05$ by Student's t-test). There was no observable change in rhodamine formation in KPB.

Figure 6 shows the intracellular oxidation of DHR 123 to the fluorescent product rhodamine following SIN-1 treatment. Peroxynitrite is an efficient oxidant of DHR 123 (Kooy et al., 1994). However, other species are capable of oxidizing DHR 123 in the cell, such as hydrogen peroxide and hydroxyl radicals. Superoxide anions do not oxidize DHR 123 (Royall and Ischiropoulos, 1993). The peroxynitrite donor (0-2 mM) increased formation of rhodamine with increased dose as indicated by the increase in fluorescence (Fig. 6a). This increase was also time-dependent (Fig. $6 b)$. Experiments to determine the ability of intracellular lycopene and $\beta$-carotene to suppress the oxidation of DHR 123 were carried out (Fig 7). Both lycopene and $\beta$-carotene inhibited DHR 123 oxidation (two-way ANOVA, carotenoids $F=6.6 ; P=0.018$, concentrations $F=18.48 ; P<0.0001$ ). The maximal inhibition was at $1 \mu \mathrm{M}$ of 47.5 and $42.4 \%$, respectively. (post hoc Tukey's test or Student's t-test with Bonferroni correction, $P \leq 0.05$ ).

\section{Discussion}


Oxidative stress has been implicated in the pathophysiology of chronic inflammatory conditions and cancer (Ohshima et al., 2003, Dedon and Tannenbaum, 2004) as well as diseases such as Alzheimer disease, Parkinson disease, amyotrophic lateral sclerosis (Beal 2002, Ischiropoulos and Beckman, 2003), and artheriosclerosis (Radomski 1995, Touyz and Schiffrin, 2004). While a large body of evidence has associated ROS such as hydroxyl radicals, hydrogen peroxide and superoxide anions in the development of disease, there is comparatively little research on the involvement of reactive nitrogen species. There is emerging interest in the role of peroxynitrite and its derived species in disease. As fruits and vegetables are linked to beneficial effects against various ailments, there is interest in identifying the particular constituents, and their mechanism(s) by which they may confer these beneficial effects. In the present study, our focus is on the carotenoids lycopene and $\beta$-carotene as there are numerous reports on their influence on oxidative stress-related conditions.

Strand breakage upon treatment with peroxynitrite has been demonstrated previously in plasmid DNA (Yermilov et al., 1996, Epe et al., 1996, Salgo et al., 1995, Yoshie and Ohshima 1997, Kennedy et al., 1997) and cells (Spencer et al., 1996). As in these earlier studies, peroxynitrite formed from SIN-1 induced strand breaks in pUC 18 DNA in this study (Fig. 1b). Induction of strand breaks by authentic peroxynitrite was similar to that of SIN-1 (Fig. 1a). The antioxidants SOD and/or catalase had no effect on peroxynitrite-induced strand breaks. In contrast, SIN-1-induced strand breaks (Fig. 1b) were inhibited SOD and also by a combination of SOD and catalase. Catalase alone was ineffective in preventing strand breaks. This finding suggests $\mathrm{H}_{2} \mathrm{O}_{2}$ was not involved in strand breaks caused by SIN-1 under the conditions used in this study. As shown in Table 1-1, there was inhibition of SIN-1-induced strand breaks in DNA by both lycopene and $\beta$-carotene (Table 1-1, Fig. 1c and d) with maximal inhibitions of 77.4 and 90.5\%, respectively. Differences between lycopene and $\beta$-carotene were analyzed by two-way ANOVA. Peroxynitrite generated from SIN-1 as well as authentic peroxynitrite cause time- and dose-dependent increases in DNA damage in V79 cells as demonstrated in figure 2. Hydrogen peroxide is generated during SIN-1 decomposition and may be implicated in DNA damage resulting from the addition of SIN-1. No formation of $\mathrm{H}_{2} \mathrm{O}_{2}$ was evident in KPB but is present in MEM (Fig. 5b). The contributory role of $\mathrm{H}_{2} \mathrm{O}_{2}$ in DNA damage under the conditions used in this study is minimal as deduced from the use of $\mathrm{H}_{2} \mathrm{O}_{2}$ and $\mathrm{O}_{2}{ }^{\circ}$ - scavengers. As in the naked plasmid DNA, lycopene and $\beta$-carotene were also very effective in reducing DNA damage in cells (Fig. 3) as measured by the alkaline comet 
assay, which detects DNA strand breaks, DNA-DNA or DNA-protein cross-links and abasic sites (Collins et al., 1997, Tice et al., 2000). The concentrations of SIN-1 used in this study were not lethal to the cells as no loss in viability was apparent. Authentic peroxynitrite was slightly toxic at higher concentrations as determined by a metabolic assay. Neither lycopene nor $\beta$-carotene was toxic to the cells. Consistent with our findings, Hiramoto et al. (1999) also found that $\beta$-carotene prevented DNA strand breaks in cells. The concentration range of carotenoids used in our study was selected on the basis of concentrations attainable in human plasma or serum (Cook et al., 1999, Furr and Clark, 1997, Prince and Frisoli, 1993). Carotenoids can exhibit pro-oxidant properties under certain conditions e.g. high oxygen tension and high concentration (El-Agamey et al., 2004). However, under our experimental conditions none of these properties were evident. These results indicate the potential of these carotenoids to offer protection against oxidative stress-related conditions.

Mechanisms of DNA strand breakage by peroxynitrite are at present not clear. However, they may involve hydrogen abstraction by peroxynitrous acid or peroxynitrite decomposition intermediates and subsequently oxygen attack on the sugar moiety leading to sugar radicals that are cleaved to form strand breaks (Szabo and Ohshima 1997). Alternatively or in addition to strand breaks arising from sugar damage, strand breaks may also arise indirectly from nucleobase damage (Burney et al., 1999, Dedon and Tannenbaum, 2004). In this case, the nucleoside damage results in formation of abasic sites which can depurinate to give rise to single strand breaks (Burney et al., 1999, Tretyakova et al., 2000). It is not clear how lycopene or $\beta$-carotene prevents peroxynitrite-induced damage to the DNA. It is probable that there is direct quenching or binding of the peroxynitrite or its intermediate(s), which are yet to be fully characterized and confirmed. Binding of lycopene or $\beta$-carotene to other RNS, such as nitrogen dioxide (Bohm et al., 1995, Kikugawa et al., 1997) has been reported previously, though the nature of the carotenoid-ROS/RNS reaction is dependent on the type of radical species involved (Mortensen et al., 1997).

We also investigated the ability of lycopene and $\beta$-carotene to modulate protein tyrosine nitration by peroxynitrite. Through the use of nitrotyrosine antibody, we show that lycopene is a potent inhibitor of protein tyrosine nitration in V79 cells (Fig. 4). Quantitation of the level of inhibition by densitometry revealed almost complete inhibition by this carotenoid at $5 \mu \mathrm{M}$. Uric acid was 
just as potent as lycopene but also had the additional effect of remarkably reducing the intensity of the band at approximately $40 \mathrm{kDa}$. Further studies are required to identify the protein involved and investigate the importance of this unique effect. While the role of protein tyrosine nitration in cell signaling has only recently began to be uncovered (Gow et al., 2004), the presence of nitrated protein adducts in tissues has also been linked to the pathogenesis of various diseases. Main proteins nitrated migrated just above 62 and $83 \mathrm{kDa}$. Amino acid analysis indicates that they are GP50 and elongation factor 2. Their precise functions in regard to protein nitration are at present not known and further study is required on this.

Considering the potent protective effect of lycopene or $\beta$-carotene on peroxynitrite-induced DNA modifications or protein tyrosine nitration, we also assessed the actual scavenging of peroxynitrite in the cells using the indicator fluoro-probe dihydrorhodamine 123 (Fig. 6 and 7). Upon treatment of cells with SIN-1, DHR 123 was oxidised to the fluorescent product rhodamine 123. Lycopene and $\beta$-carotene more than halved rhodamine formation (Fig.7). This result shows that carotenoids incorporated into the cells are capable of scavenging peroxynitrite. As mentioned earlier, scavenging of peroxynitrite by lycopene or $\beta$-carotene in solution and in low density lipoproteins has been shown previously (Panasenko et al., 2000, Pannala et al., 1998).

In conclusion, we have demonstrated that intracellular lycopene and $\beta$-carotene are capable of protecting cells against DNA damage caused by peroxynitrite formed from the simultaneous generation of superoxide and nitric oxide. These carotenoids are also potent inhibitors of single strand breaks in plasmid DNA. This finding helps to explain why fruits and vegetables are often linked to lower risks in the development of some pathological processes such as cancer, chronic inflammation, and cardiovascular and neurological diseases. In combination with various other mechanisms that may be at work such as stimulation of gap junctional communications and immunomodulation, the antioxidant properties of carotenoids may guard against the deleterious effects of oxidative stress.

\section{Acknowledgements}

We thank Mr. Yukichi Abe (Center for Instrumental Analysis, Hokkaido University) for his help in protein sequence determination. The study was partly supported by grants-in-aid for Scientific 
Research from the Ministry of Education, Science and Culture of Japan awarded to S. Fujita (No. 15201009) and to M. Ishizuka (No. 15688010). The results presented in this manuscript do not pose a conflict of interest for the authors involved.

\section{References}

Ames B.N., Shigenaga M.K., Hagen T.M. 1993. Oxidants, antioxidants, and the degenerative diseases of aging. Proc. Natl. Acad. Sci. USA. 90, 7915-7922.

Beal M.F. 2002. Oxidatively modified proteins in aging and disease. Free Radic. Biol. Med. 32, 797-803.

Bohm F., Tinkler J.H., Truscott T.G. 1995. Carotenoids protect against cell membrane damage by the nitrogen dioxide radical. Nat. Med. 1, 98-99.

Burney S., Caulfield J.L., Niles J.C., Wishnok J.S., Tannenbaum S.R. 1999. The chemistry of DNA damage from nitric oxide and peroxynitrite. Mutat. Res. 424, 37-49.

Beckman J.S. 1996. Oxidative damage and tyrosine nitration from peroxynitrite. Chem. Res. Toxicol. 9, 836-844.

Collins A.R., Dobson V.L., Dusinska M., Kennedy G., Stetina R. 1997. The comet assay: what can it really tell us? Mutat. Res. 375, 183-193.

Collins A.R., Dusinska M. 2002. Oxidation of cellular DNA measured with the comet assay. Methods. Mol. Biol. 186, 147-159.

Cook N.R., Stampfer M.J., Ma J., Manson J.E., Sacks F.M., Buring J., Hennekens C.E. 1999. Beta-carotene supplementation of low baseline levels and decreased risk of total and prostate cancer. Cancer. 86, 1783-1792.

Dedon P.C., Tannenbaum S.R. 2004. Reactive nitrogen species in the chemical biology of inflammation. Arch. Biochem. Biophys. 423, 12-22.

El-Agamey A., Lowe G.M., McGarvey D.J., Mortensen A., Phillip D.M., Truscott T.G., Young A.J. 2004. Carotenoid radical chemistry and antioxidant/pro-oxidant properties. Arch. Biochem. Biophys. 430, 37-48.

Epe B., Hegler J. 1994. Oxidative DNA damage: endonuclease fingerprinting. Methods Enzymol. 234, 122-131.

Epe B., Ballmaier D., Roussyn I., Briviba K,. Sies H. 1996. DNA damage by peroxynitrite characterized with DNA repair enzymes. Nucleic Acids Res. 24, 4105-4110.

Furr H,C,, Clark R,M. 1997. Intestinal absorption and tissue distribution of carotenoids J. Nutr. Biochem. 8, 364-377. 
Glei M., Liegibel U.M., Ebert M.N., Bohm V., Pool-Zobel B.L. 2002. Beta-Carotene reduces bleomycin-induced genetic damage in human lymphocytes. Toxicol. Appl. Pharmacol. 179, 65-73.

Gow A.J., Farkouh C.R., Munson D.A., Posencheg M.A., Ischiropoulos H. 2004. Biological significance of nitric oxide-mediated protein modifications. Am. J. Physiol. Lung Cell. Mol. Physiol. 287, 262-268.

Hiramoto K., Tomiyama S., Kikugawa K. 1999. Effective inhibition by beta-carotene of cellular DNA breaking induced by peroxynitrous acid. Free Radic. Res. 30, 21-27.

Ischiropoulos H., Beckman J.S. 2003. Oxidative stress and nitration in neurodegeneration: cause, effect, or association? J. Clin. Investig. 111, 163-169.

Josephy P.D., Eling T., Mason R.P. 1982. The horseradish peroxidase-catalyzed oxidation of 3,5,3',5'-tetramethylbenzidine. Free radical and charge-transfer complex intermediates. J. Biol. Chem. 257, 3669-3675.

Kennedy L.J., Moore K. Jr,, Caulfield J.L, Tannenbaum S.R., Dedon P.C. 1997. Quantitation of 8-oxoguanine and strand breaks produced by four oxidizing agents. Chem. Res. Toxicol. 10, 386-392.

Kikugawa K., Hiramoto K., Tomiyama S., Asano Y. 1997. Beta-Carotene effectively scavenges toxic nitrogen oxides: nitrogen dioxide and peroxynitrous acid. FEBS Lett. 404, 175-178.

Kirsch M. and de Groot H. 1999. Reaction of peroxynitrite with reduced nicotinamide nucleotides, the formation of hydrogen peroxide. J. Biol. Chem. 274, 24664-24670.

Kooy N.W., Royall J.A., Ischiropoulos H., Beckman J.S. 1994. Peroxynitrite-mediated oxidation of dihydrorhodamine 123. Free Radic. Biol. Med. 16, 149-156.

Koppenol W.H., Moreno J.J., Pryor W.A., Ischiropoulos H., Beckman J.S. 1992. Peroxynitrite, a cloaked oxidant formed by nitric oxide and superoxide. Chem. Res. Toxicol. 5, 834-842.

Li Y., Trush M.A. 1993. DNA damage resulting from the oxidation of hydroquinone by copper: role for a $\mathrm{Cu}(\mathrm{II}) / \mathrm{Cu}(\mathrm{I})$ redox cycle and reactive oxygen generation. Carcinogenesis 14, 1303-1311.

Liu X., Yao J., Pisha E., Yang Y., Hua Y., van Breemen R.B. and Bolton J.L. 2002. Oxidative DNA damage induced by equine estrogen metabolites: role of estrogen receptor alpha. Chem. Res. Toxicol. 15, 512-519.

Lomonosova E.E., Kirsch M., Rauen U. and de Groot H. 1998. The critical role of HEPES in SIN-1 cytotoxicity, peroxynitrite versus hydrogen peroxide. Free Radic. Biol. Med. 24, 522-528.

Lowe G.M., Booth L.A., Young A.J., Bilton R.F. 1999. Lycopene and beta-carotene protect against oxidative damage in HT29 cells at low concentrations but rapidly lose this capacity at higher doses. Free Radic. Res. 30, 141-151. 
Lowry O.H., Rosenbrough N.J., Farr A.L., Randall R.J. 1951. Protein measurement with the Folin phenol reagent. J. Biol. Chem. 193, 265-275.

Matos H.R., Di Mascio P., Medeiros M.H. 2000. Protective effect of lycopene on lipid peroxidation and oxidative DNA damage in cell culture. Arch. Biochem. Biophys. 383, 56-59.

Mortensen A., Skibsted L.H., Sampson J., Rice-Evans C., Everett S.A. 1997. Comparative mechanisms and rates of free radical scavenging by carotenoid antioxidants. FEBS Lett. 418, 91-97.

Muzandu K., El Bohi K., Shaban Z., Ishizuka M., Kazusaka A., Fujita S. 2005a. Lycopene and beta-carotene ameliorate catechol estrogen-mediated DNA damage. Jpn. J. Vet. Res. 52, 173-184.

Muzandu K., Shaban Z., Ishizuka M., Kazusaka A., Fujita S. 2005b. Nitric oxide enhances catechol estrogen-induced oxidative stress in LNCaP cells. Free Rad. Res. 39, 389-398.

Ohshima H., Tatemichi M., Sawa T. 2003. Chemical basis of inflammation-induced carcinogenesis. Arch. Biochem. Biophys. 417, 3-11.

Panasenko O.M., Sharov V.S., Briviba K., Sies H. 2000. Interaction of peroxynitrite with carotenoids in human low density lipoproteins. Arch. Biochem. Biophys. 373, 302-305.

Pannala A.S., Rice-Evans C,. Sampson J., Singh S. 1998. Interaction of peroxynitrite with carotenoids and tocopherols within low density lipoprotein. FEBS Lett. 423, 297-301.

Pietraforte D., Salzano A.M., Marino G., Minetti M. 2003. Peroxynitrite-dependent modifications of tyrosine residues in hemoglobin. Formation of tyrosyl radical(s) and 3-nitrotyrosine. Amino Acids 25, 341-350.

Prince M.R., Frisoli J.K. 1993. Beta-carotene accumulation in serum and skin. Am. J. Clin. Nutr. 57, 175-181.

Radi R., Beckman J.S., Bush K.M., Freeman B.A. 1991. Peroxynitrite oxidation of sulfhydryls. The cytotoxic potential of superoxide and nitric oxide. J. Biol. Chem. 1991 266, 4244-4250.

Radomski M.W., Salas E. 1995. Nitric oxide--biological mediator, modulator and factor of injury: its role in the pathogenesis of atherosclerosis. Atherosclerosis. 118, S69-S80.

Royall J.A., Ischiropoulos H. 1993. Evaluation of 2',7'-dichlorofluorescin and dihydrorhodamine 123 as fluorescent probes for intracellular H2O2 in cultured endothelial cells. Arch. Biochem. Biophys. 302, 348-355.

Salgo M.G., Stone K., Squadrito G.L., Battista J.R., Pryor W.A. 1995 Peroxynitrite causes DNA nicks in plasmid pBR322. Biochem. Biophys. Res. Commun. 210, 1025-1030.

Schierle J., Bretzel W., Bühler I., Faccin N., Hess D., Steiner K., Schüep W. 1997. Content and isomeric ratio of lycopene in food and human blood plasma. Food Chem. 59, 459-465. 
Singh N.P., McCoy M.T., Tice R.R., Schneider E.L. 1988. A simple technique for quantitation of low levels of DNA damage in individual cells. Exp. Cell. Res. 175, 184-191.

Spencer J.P.E., Wong J., Jenner A., Aruoma O.I., Cross C.E., Halliwell B. 1996. Base modification and strand breakage in isolated calf thymus DNA and in DNA from human skin epidermal keratinocytes exposed to peroxynitrite or 3-morpholinosydnonimine. Chem. Res. Toxicol. 9, 1152-1158.

Szabo C., Ohshima H. 1997. DNA damage induced by peroxynitrite: subsequent biological effects. Nitric Oxide. 1, 373-385.

Tice R.R., Agurell E., Anderson D., Burlinson B., Hartmann A., Kobayashi H., Miyamae Y., Rojas E., Ryu J.C., Sasaki Y.F. 2000. Single cell gel/comet assay: guidelines for in vitro and in vivo genetic toxicology testing. Environ. Mol. Mutagen 35, 206-221.

Touyz R.M., Schiffrin E.L. 2004. Reactive oxygen species in vascular biology: implications in hypertension. Histochem. Cell. Biol. 122, 339-352.

Tretyakova N.Y., Burney S., Pamir B., Wishnok J.S., Dedon P.C., Wogan G.N., Tannenbaum S.R. 2000. Peroxynitrite-induced DNA damage in the supF gene: correlation with the mutational spectrum. Mutat. Res. 447, 287-303.

Weitberg A.B., Weitzman S.A., Clark E.P., Stossel T.P. 1985. Effects of antioxidants on oxidant-induced sister chromatid exchange formation. J. Clin. Invest. 75, 1835-1841.

Woods J.A., Bilton R.F., Young A.J. 1999. Beta-carotene enhances hydrogen peroxide-induced DNA damage in human hepatocellular HepG2 cells. FEBS Lett. 449, 255-258.

Yeh S.L., Hu M.L. 2001. Induction of oxidative DNA damage in human foreskin fibroblast Hs68 cells by oxidized beta-Carotene and lycopene. Free Radic. Res. 35, 203-213.

Yermilov V., Yoshie Y., Rubio J., Ohshima H. 1996. Effects of carbon dioxide/bicarbonate on induction of DNA single-strand breaks and formation of 8-nitroguanine, 8-oxoguanine and base-propenal mediated by peroxynitrite. FEBS Lett. 399, 67-70.

Yoshie Y., Ohshima H. 1997. Nitric oxide synergistically enhances DNA strand breakage induced by polyhydroxyaromatic compounds, but inhibits that induced by the Fenton reaction. Arch. Biochem. Biophys. 342, 13-21. 
Tables

Table 1-1. Effect of lycopene and $\beta$-carotene on strand breaks induced by the peroxynitrite donor, SIN-1, in pUC18 plasmid DNA†.

\begin{tabular}{|c|c|c|c|c|}
\hline \multirow{3}{*}{ Concentration $(\mu \mathrm{M}) \S$} & \multicolumn{2}{|c|}{ Lycopene } & \multicolumn{2}{|c|}{$\beta$-Carotene } \\
\hline & & \% control\# & & \% control\# \\
\hline & bp DNA & & bp DNA & \\
\hline 0.00 (control) & $1.37 \pm 0.12^{\mathrm{a}}$ & 100.0 & $1.42 \pm 0.13^{\mathrm{a}}$ & 100.0 \\
\hline 0.05 & $1.36 \pm 0.03^{\mathrm{a}}$ & 99.6 & $1.44 \pm 0.19^{\mathrm{a}}$ & 101.0 \\
\hline 0.10 & $1.04 \pm 0.07^{b}$ & 76.0 & $1.05 \pm 0.14^{\mathrm{ab}}$ & 74.0 \\
\hline 0.25 & $0.72 \pm 0.07^{\mathrm{c}}$ & 52.8 & $0.77 \pm 0.16^{\mathrm{bc}}$ & 54.2 \\
\hline 0.50 & $0.55 \pm 0.04^{\mathrm{cd}}$ & 40.3 & $0.41 \pm 0.07^{\mathrm{cd}}$ & 28.8 \\
\hline 1.00 & $0.47 \pm 0.02^{\mathrm{cd} *}$ & 34.2 & $0.19 \pm 0.02^{d}$ & 13.3 \\
\hline 2.50 & $0.38 \pm 0.02^{\mathrm{d}} *$ & 27.9 & $0.16 \pm 0.01^{\mathrm{d}}$ & 11.4 \\
\hline 5.00 & $0.32 \pm 0.03^{d_{*}}$ & 23.3 & $0.14 \pm 0.02^{d}$ & 9.5 \\
\hline 10.00 & $0.31 \pm 0.02^{\mathrm{d}_{*}}$ & 22.6 & $0.13 \pm 0.02^{d}$ & 9.5 \\
\hline
\end{tabular}

†DNA was incubated with carotenoids or vehicle (THF) and/or SIN-1 for 30 min at $37^{\circ} \mathrm{C}$ (See Materials and methods for details). DNA damage was expressed as single strand breaks (SSB) per $10^{4}$ base pairs (bp) DNA. Data are means \pm SEM of 3 experiments. §Concentration of carotenoid $+50 \mu \mathrm{M}$ SIN-1. \#Percentage of SSB in pUC18 plasmid DNA calculated relative to control.

Differences were evaluated by two-way ANOVA and post hoc tests. A common letter indicated no difference amongst data in each carotenoid treated group (post hoc Tukey's-test, $P \leq 0.05$ ). *Different from same concentration of $\beta$-carotene treatment (post hoc Student's t-test with Bonferroni correction, $P \leq 0.05)$. 
Table 2-1. Cell viability as determined by the CCK-8 assay

\begin{tabular}{|c|c|c|c|}
\hline & \multicolumn{3}{|c|}{ Viability (\% of control) } \\
\hline Concentration & Decomposed & SIN-1 & $\mathrm{PN}$ \\
\hline$(\mu \mathrm{M})$ & SIN-1 & & \\
\hline Control (non-treated) & & $100 \pm 0.0$ & $100 \pm 0.0$ \\
\hline 0 (vehicle only) & & $97.6 \pm 3.0$ & $97.4 \pm 0.7^{\mathrm{ab}}$ \\
\hline 10 & & $101.2 \pm 1.1$ & $100.8 \pm 0.4^{\mathrm{a}}$ \\
\hline 50 & & $100.0 \pm 5.5$ & $99.4 \pm 1.2^{\mathrm{a}}$ \\
\hline 100 & & $100.2 \pm 3.0$ & $97.3 \pm 1.5^{a b}$ \\
\hline 250 & & $101.1 \pm 3.5$ & $86.3 \pm 2.6^{\mathrm{C} *}$ \\
\hline 500 & & $97.0 \pm 2.8$ & $87.2 \pm 3.5^{\mathrm{bc} *}$ \\
\hline 1000 & $98.3 \pm 7.6$ & $98.0 \pm 3.2$ & $88.5 \pm 3.1^{\mathrm{bc}}$ \\
\hline
\end{tabular}

Mean ( \pm SE, $n=3$ replicates/treatment) cell viability expressed as \% of control (non-treated cells). Vehicle used was $\mathrm{NaOH}$ at a final concentration of $10 \mu \mathrm{M}$. PN, authentic peroxynitrite. Differences were evaluated using two-way ANOVA followed by post hoc tests. A common letter indicated no difference amongst data of SIN-1 or PN treated groups (post hoc Tukey's test, $P \leq 0.05$ ). *Different from same concentration SIN-1 treatment (post hoc Student's t-test with Bonferroni correction, $P \leq 0.05$ ).

Table 2-2. Cell viability after treatment with SIN-1 or authentic peroxynitrite (PN) as determined by trypan blue dye exclusion

\begin{tabular}{ccccc}
\hline & & \multicolumn{3}{c}{ Viability (\%) } \\
\hline Concentration & $\begin{array}{c}\text { Vehicle }(\mathrm{NaOH}) \\
(\text { control })\end{array}$ & $\begin{array}{c}\text { Decomposed } \\
\text { SIN-1 }\end{array}$ & SIN-1 & PN \\
\hline $10 \mu \mathrm{M}$ & $95.2 \pm 1.8$ & - & - & - \\
$10 \mu \mathrm{M}$ & - & - & $94.4 \pm 1.9$ & $95.8 \pm 1.5$ \\
$100 \mu \mathrm{M}$ & - & - & $94.1 \pm 1.9$ & $95.4 \pm 1.2$ \\
$1000 \mu \mathrm{M}$ & - & $93.4 \pm 1.2$ & $93.7 \pm 2.1$ & $92.5 \pm 1.8$
\end{tabular}

Mean ( \pm SE, $n=3$ replicates/treatment) cell viability expressed as \% viable cells, based on trypan blue staining of non-viable cells. PN, authentic peroxynitrite. $P>0.05$ by two-way ANOVA. 
Table 2-3. Cell viability after treatment with carotenoids as determined by trypan blue dye exclusion

\begin{tabular}{ccccc}
\hline \multicolumn{5}{c}{ Viability (\%) } \\
\hline $\begin{array}{c}\text { Carotenoid } \\
\text { concentration } \\
(\mu \mathrm{M})\end{array}$ & lycopene & $\beta$-carotene & $\begin{array}{c}\text { Lycopene } \\
+ \text { SIN-1 }\end{array}$ & $\begin{array}{c}\beta \text {-carotene } \\
+ \text { SIN-1 }\end{array}$ \\
\hline 0.0 & - & & & \\
0.312 & $93.1 \pm 2.6$ & $89.5 \pm 2.5$ & $93.7 \pm 1.6$ & $90.9 \pm 2.1$ \\
0.625 & $94.4 \pm 0.6$ & $90.9 \pm 1.5$ & $93.3 \pm 1.9$ & $90.0 \pm 2.9$ \\
1.25 & $93.4 \pm 2.8$ & $89.4 \pm 1.8$ & $93.4 \pm 1.5$ & $89.3 \pm 1.4$ \\
2.5 & $93.1 \pm 2.4$ & $89.2 \pm 2.3$ & $92.1 \pm 2.2$ & $89.5 \pm 1.3$ \\
5 & $94.2 \pm 1.9$ & $90.2 \pm 1.9$ & $93.6 \pm 1.9$ & $88.0 \pm 0.7$ \\
10 & $93.5 \pm 2.4$ & $90.8 \pm 2.7$ & $93.2 \pm 2.3$ & $89.3 \pm 3.4$
\end{tabular}

Mean ( \pm SE, $n=3$ replicates/treatment) cell viability expressed as \% viable cells, based on trypan blue staining of non-viable cells. SIN-1 concentration used was $1 \mathrm{mM}$. THF (vehicle, $0.2 \%$ ) only viability was $96.6 \pm 1.0 \quad \%$ and $92.6 \pm 3.6 \quad \% \quad$ in the lycopene and $\beta$-carotene treatments, respectively. Concentration "0.0" $\mu \mathrm{M}$ refers to SIN-1 (1000 $\mu \mathrm{M})$ plus THF only. $P>0.05$ by two-way ANOVA. 


\section{Figure legends}

Figure 1. Induction of strand breaks in pUC18 DNA. (a) DNA was incubated with 0-100 $\mu \mathrm{M}$ SIN-1 alone for $30 \mathrm{~min}$ at $37^{\circ} \mathrm{C}$. The concentration at $0 \mu \mathrm{M}$ contained $10 \mathrm{mM} \mathrm{NaOH}$, the vehicle used for SIN-1. (b) DNA was incubated for $30 \mathrm{~min}$ at $37^{\circ} \mathrm{C}$ with either vehicle only (0.1 \% THF) or $0.25-10$ $\mu \mathrm{M}$ lycopene plus $100 \mu \mathrm{M}$ SIN-1. (c) DNA was incubated for $30 \mathrm{~min}$ at $37^{\circ} \mathrm{C}$ with either vehicle only (0.1\% THF) or 0.25-10 $\mu \mathrm{M} \beta$-carotene plus $100 \mu \mathrm{M}$ SIN-1. (See Materials and methods for details). OC, open circular DNA; SC, supercoiled DNA.

Figure 2. Effect of SIN-1 or authentic peroxynitrite (PN) on DNA damage in Chinese hamster lung fibroblasts (V79) cells. (a) Cells were exposed to $1000 \mu \mathrm{M}$ SIN-1 or PN for the indicated times in MEM at $37^{\circ} \mathrm{C}$. Data are expressed as means \pm S.E.M. and statistically analyzed using two-way ANOVA followed by Tukey's test. A common letter indicated no difference amongst data of each reagent treated group $(P \leq 0.05)$. (b) Effect of different concentrations of SIN-1 or PN on DNA damage in cells following exposure for 1 hour. A common letter indicated no difference amongst data (Two-way ANOVA followed by Tukey's-test, $P \leq 0.05$ ). In some treatments, superoxide dismutase (SOD) and/or catalase at $500 \mathrm{U} / \mathrm{ml}$ was also added prior to exposure to $1000 \mu \mathrm{M}$ SIN-1 or PN. The effects of SOD and/or catalase are statistically analyzed using two-way ANOVA followed by Tukey’s test in SIN-1 or PN treated group, respectively. *Various SIN-1 treatments different from $1000 \mu \mathrm{M}$ SIN-1 alone, $P \leq 0.05$.

Figure 3. Effect of lycopene (a) and $\beta$-carotene (b) on cellular DNA damage caused by SIN-1. V79 cells were incubated with media containing 0 to $10 \mu \mathrm{M}$ lycopene $(\mathrm{n}=3)$ or $\beta$-carotene $(\mathrm{n}=4)$ for $24 \mathrm{~h}$ and then exposed to $1 \mathrm{mM}$ SIN-1 for $1 \mathrm{~h}$ (See "Materials and methods"). DNA damage by $1 \mathrm{mM}$ of SIN-1 was assessed with the comet assay. Data are expressed as means \pm S.E.M. A common letter indicated no difference amongst data (Tukey’s test, $P \leq 0.05$ ).

Figure 4. Carotenoids reduce nitrotyrosine formation. (a) Western blotting reveals an increase in nitration of proteins with SIN-1 treatment of cells (left panel). Nitration by SIN-1 (1 mM) is inhibited 
by antioxidants uric acid $(1 \mathrm{mM})$ as well as by lycopene $(5 \mu \mathrm{M})$ (right panel). (b) Densitometric analysis of each lane from $\sim 47.5 \mathrm{kDa}$ to $\sim 100 \mathrm{kDa}$ showing differences in nitrotyrosine formation is presented. Total pixel intensity was taken in the said region of each lane. Data are expressed as mean pixel intensity normalized to actin and relative to the control (vehicle; $\mathrm{NaOH}$ or THF). Error bars represent standard error of the mean from 4 experiments. A common letter indicated no difference amongst data (Tukey’s test, $P \leq 0.05$ ).

Figure 5. Determination of peroxynitrite formation from SIN-1. (a) Time-dependent oxidation of 500 $\mu \mathrm{M}$ dihydrorhodamine 123 to rhodamine by $50 \mu \mathrm{M}$ SIN-1 in $0.1 \mathrm{M}$ potassium phosphate buffer (KPB), pH 7.4 or in Eagle’s Minimum Essential Medium (MEM) at $37^{\circ} \mathrm{C}$. (b) Yield of rhodamine from $500 \mu \mathrm{M}$ DHR123 upon exposure to $50 \mu \mathrm{M}$ SIN-1 for 4 hours in $0.1 \mathrm{M}$ potassium phosphate buffer (KPB), pH 7.4 or in Eagle's Minimum Essential Medium (MEM) at $37^{\circ} \mathrm{C}$ in the presence or absence of $500 \mathrm{U} / \mathrm{ml}$ catalase. Vehicle is $10 \mu \mathrm{M} \mathrm{NaOH}$. * Values different from SIN-1 alone treatment (Student's t-test, $P \leq 0.05$ ).

Figure 6. Intracellular oxidation of dihydrorhodamine 123 to rhodamine by SIN-1. Chinese hamster lung fibroblasts (V79 cells) were loaded with $5 \mu \mathrm{M}$ DHR123 and incubated for $2 \mathrm{~h}$ at $37^{\circ} \mathrm{C}$ as described in "Materials and methods". (a) Increase in rhodamine formation is dose-dependent upon treatment of cells with SIN-1 for $60 \mathrm{~min}$. (b) Increase in rhodamine formation is time-dependent upon treatment of cells with SIN-1.

Figure 7. Modulation of SIN-1-induced dihydrorhodamine oxidation by lycopene and $\beta$-carotene. Cells were incubated with lycopene (white bars), $\beta$-carotene (black bars) or THF (vehicle) for $24 \mathrm{~h}$. After loading with DHR123, cells were treated with $1 \mathrm{mM} \mathrm{SIN-1} \mathrm{for} 1 \mathrm{~h}$. Results are expressed as percentage fluorescence relative to the control (SIN-1 + THF only-treated cells). Error bars represent standard error of the mean from 3 experiments. A common letter indicated no difference amongst data (Two-way ANOVA followed by Tukey's test, $P \leq 0.05$ ). * Values different between different carotenoid treatments (Two-way ANOVA followed by Student's t-test with Bonferroni correction, $P \leq$ 0.05). 


\section{Figures}

\section{Fig 1.}

a)
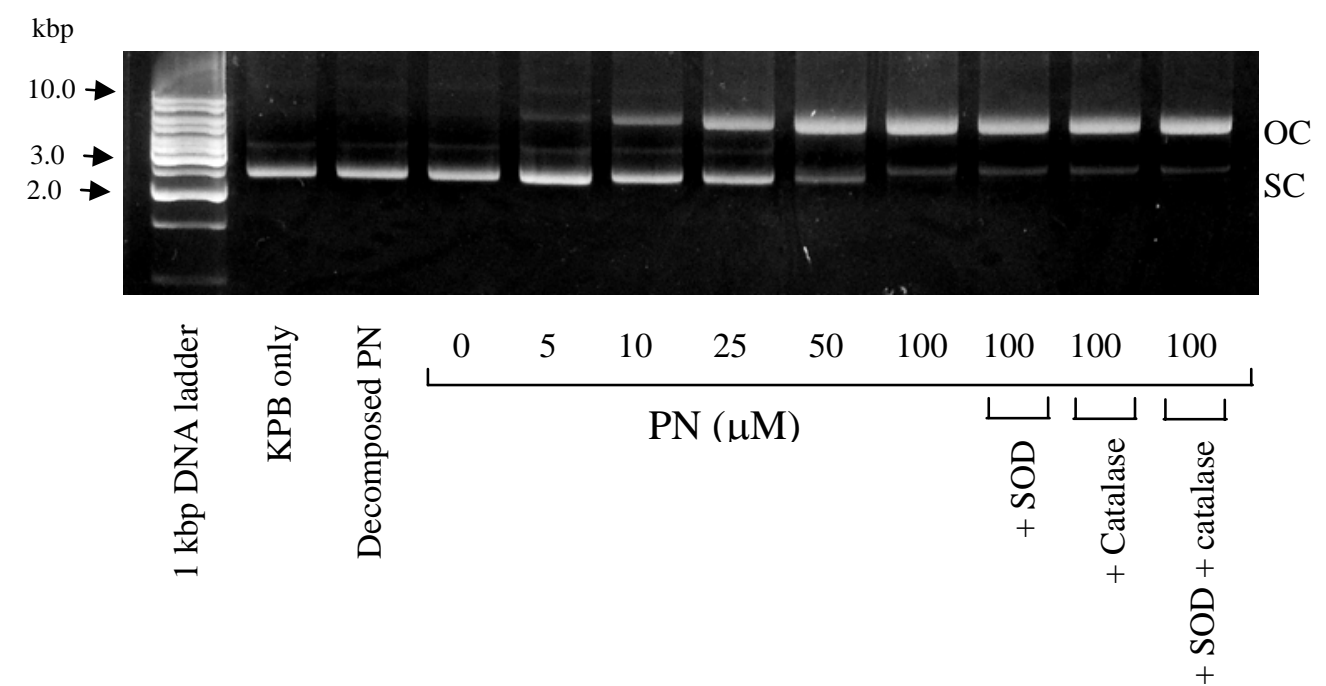

b)
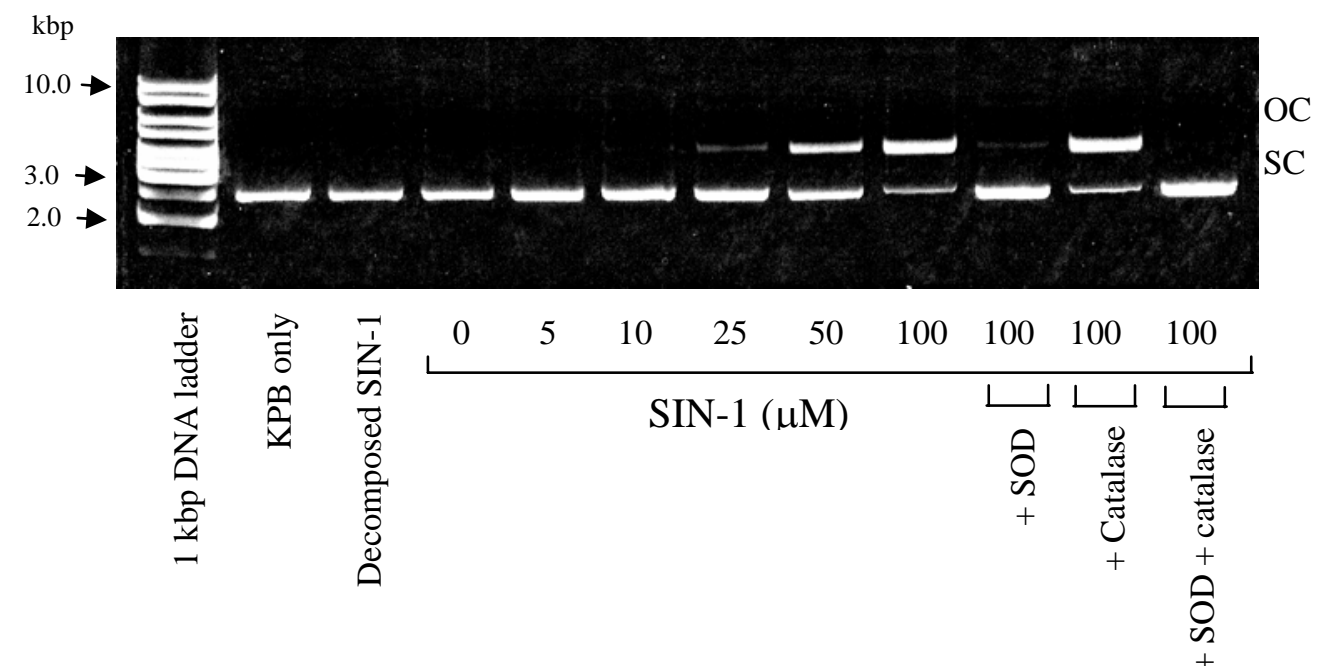

(c)

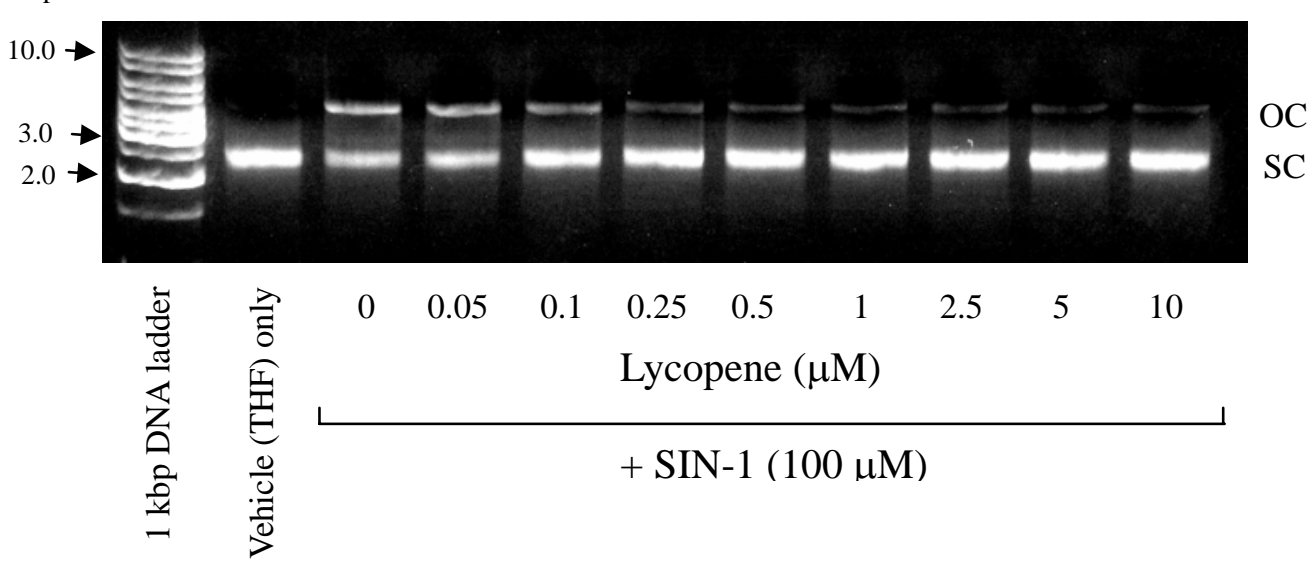


(d)

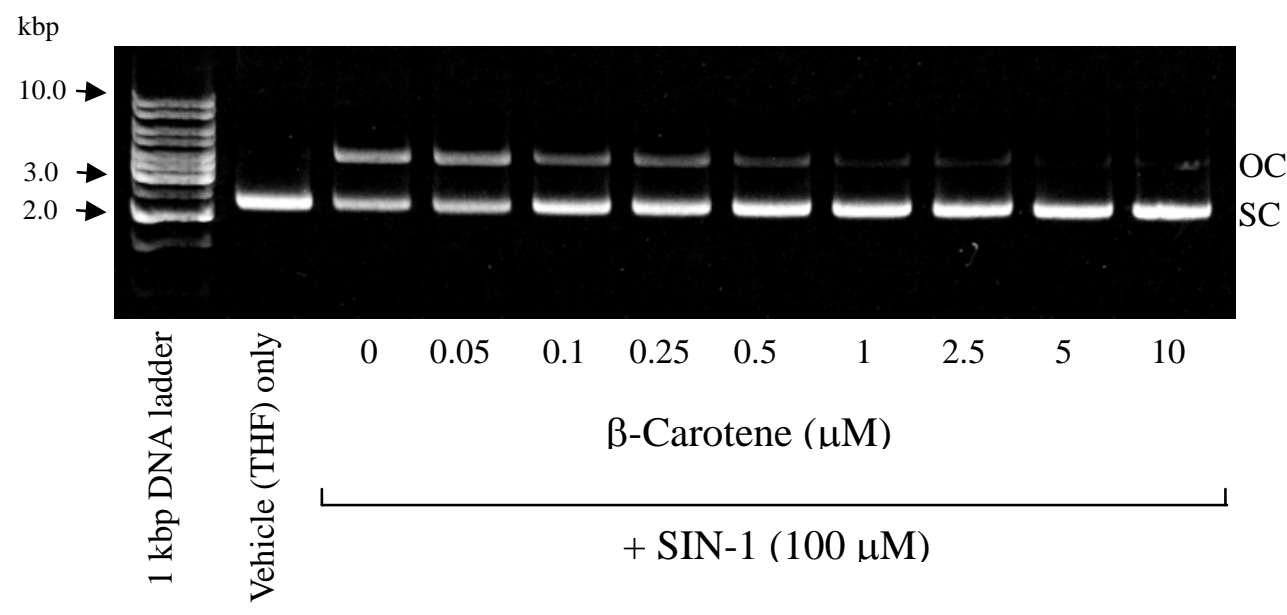


Fig. 2.

a)

b)
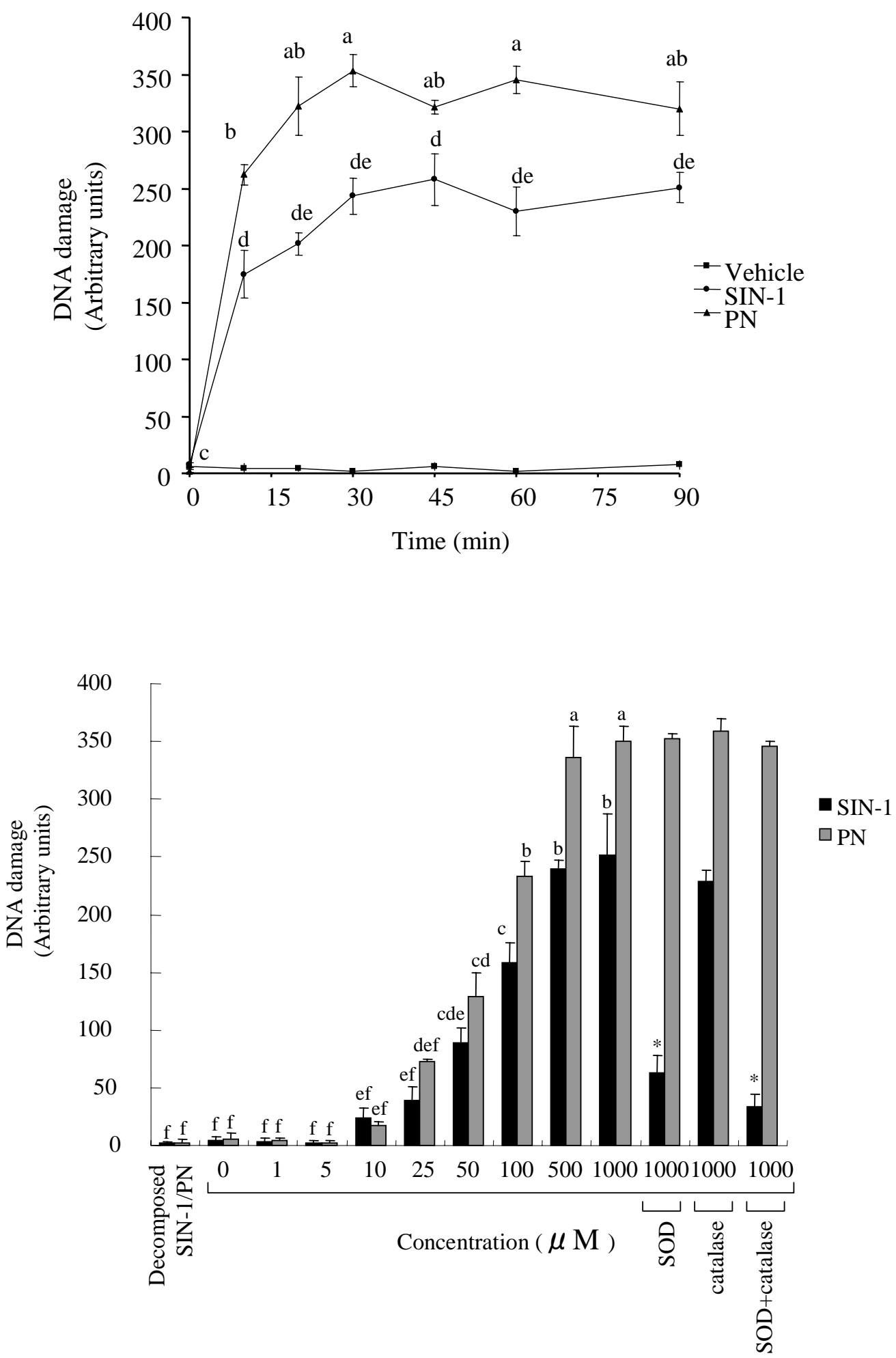
Fig. 3.

a)

b)
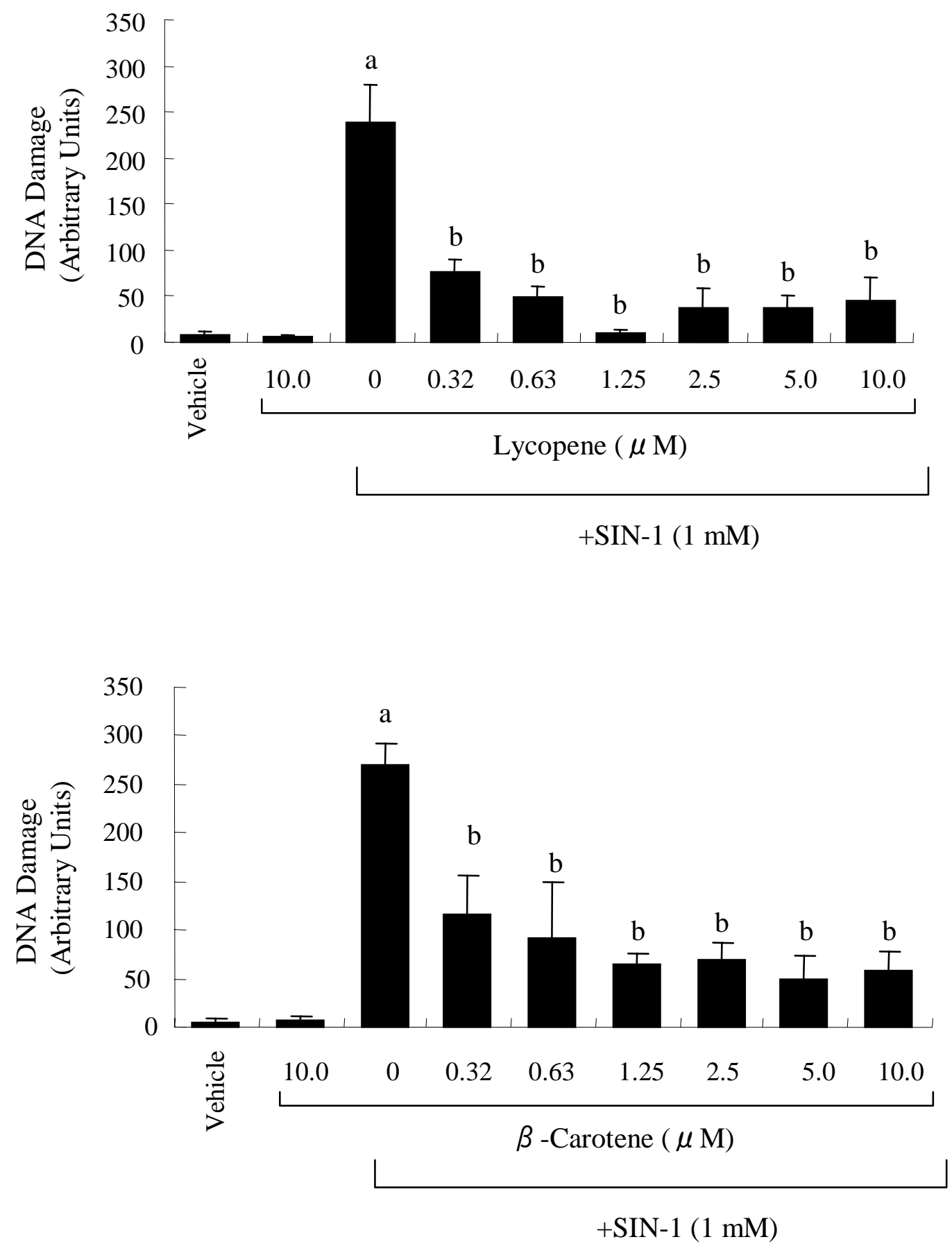
Fig. 4.

(a)

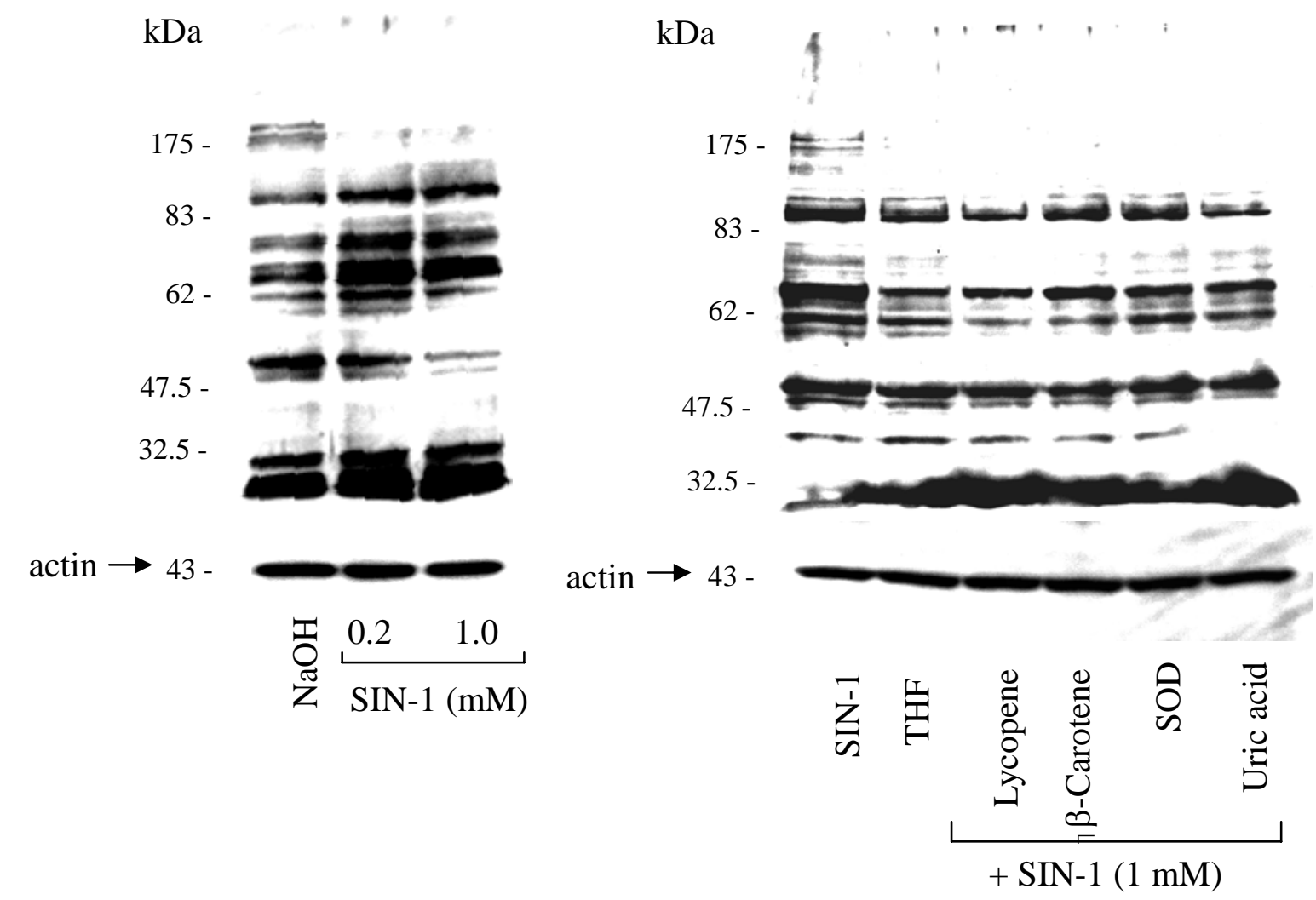

(b)
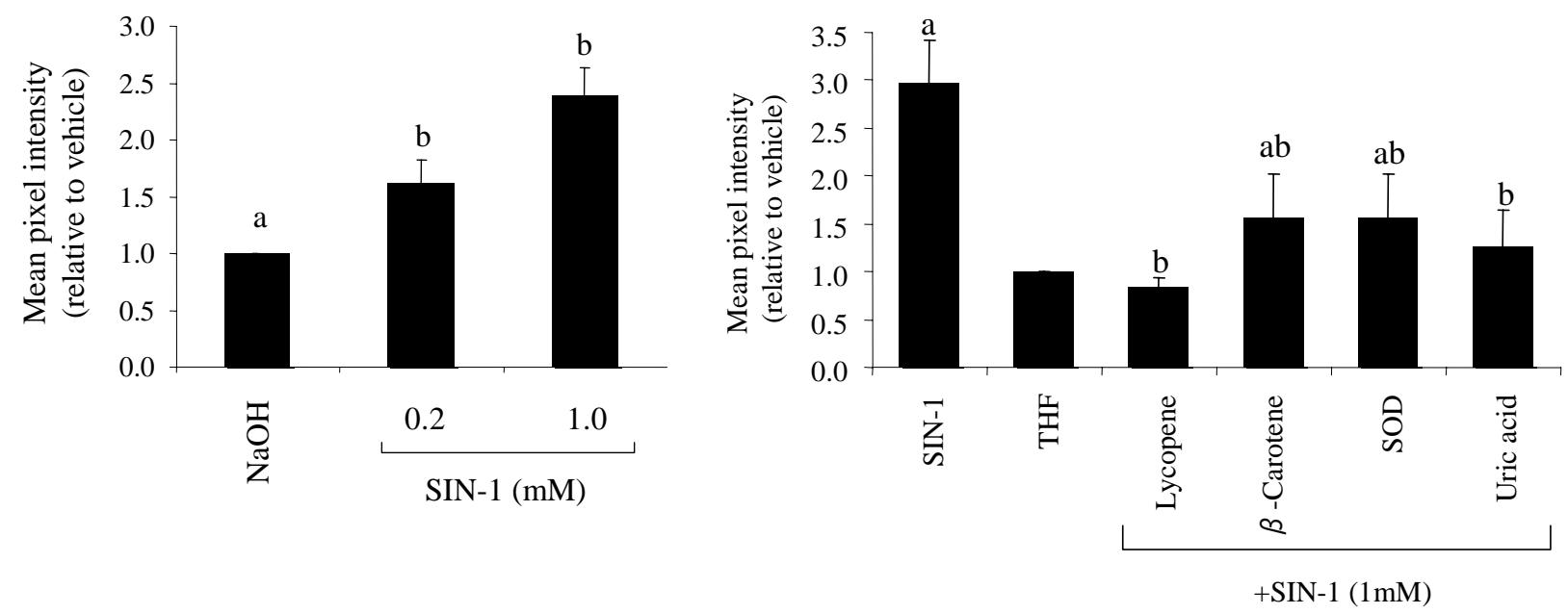
Fig. 5.

(a)

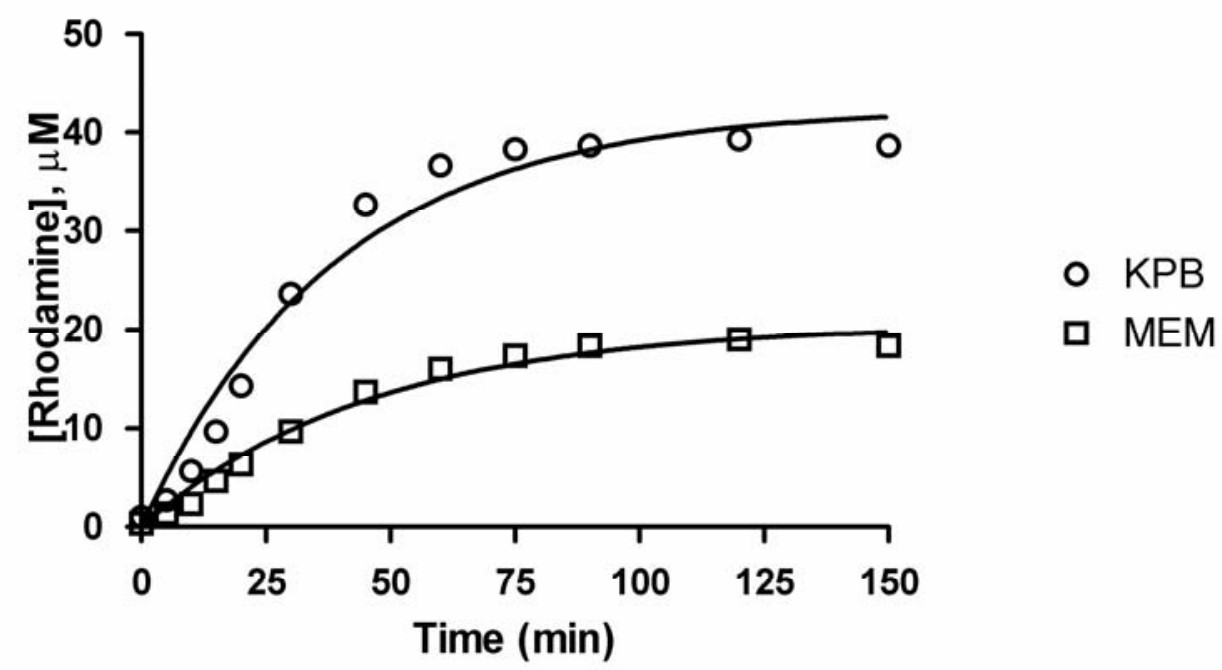

(b)

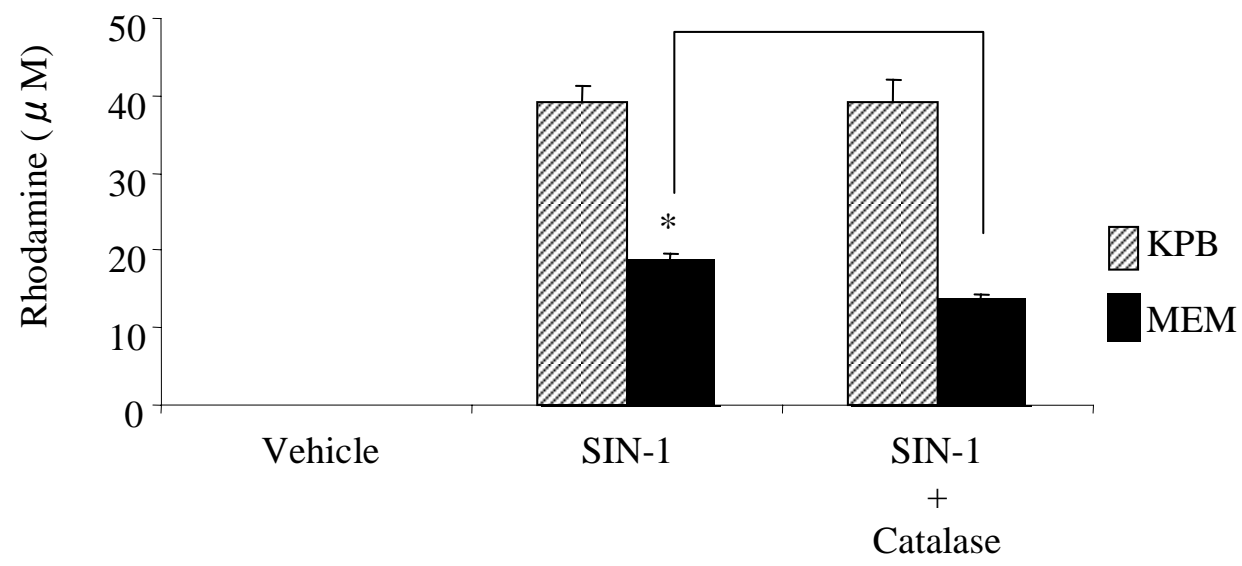


Fig. 6.

(a)

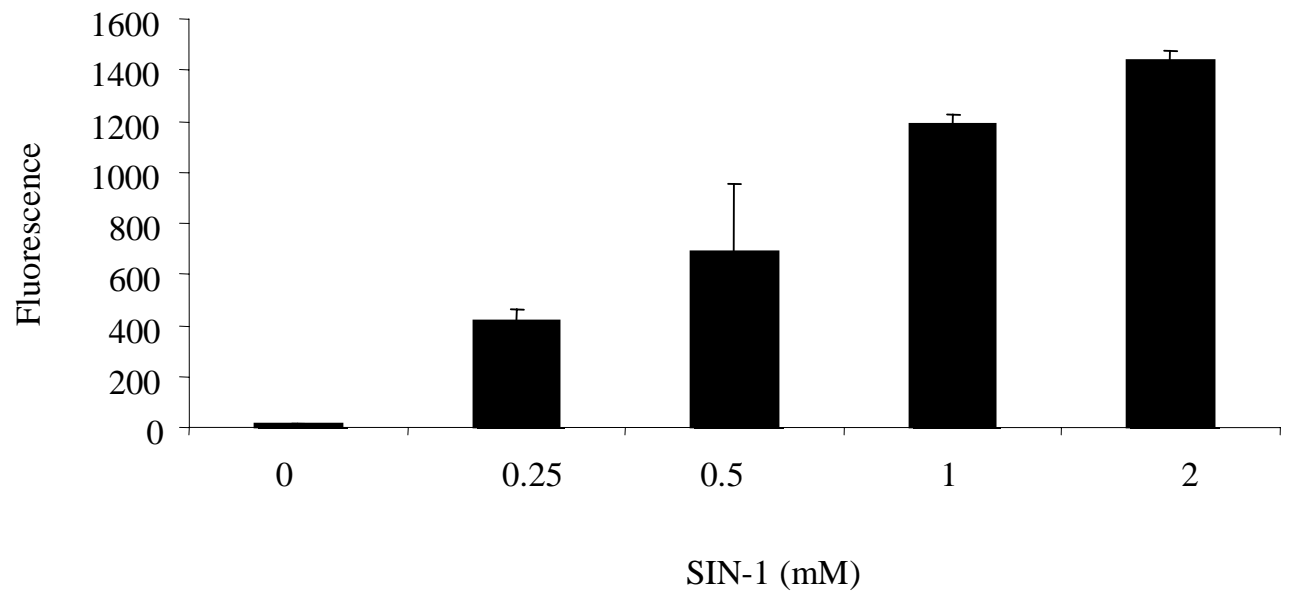

(b)

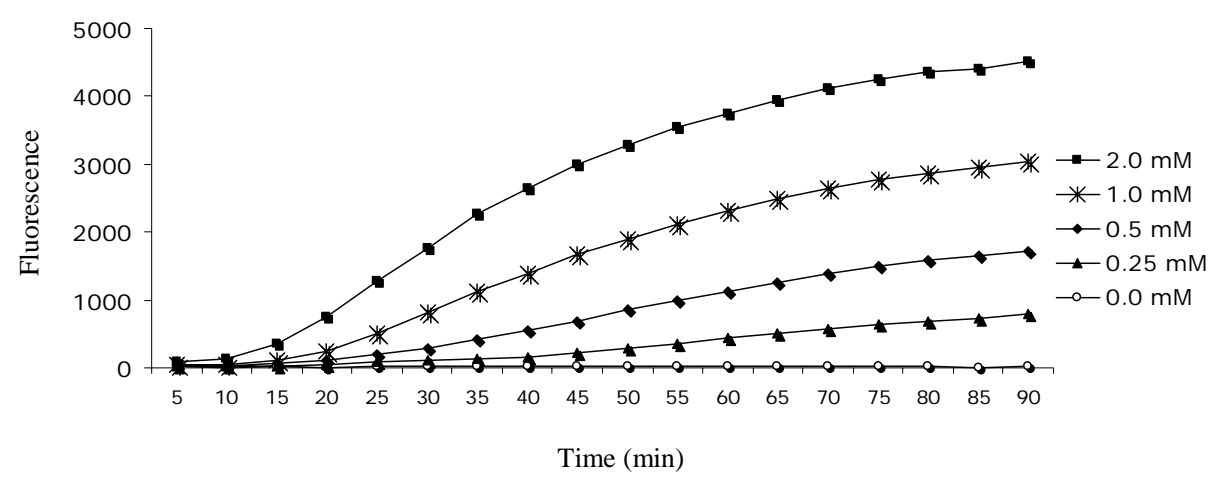

Fig. 7.

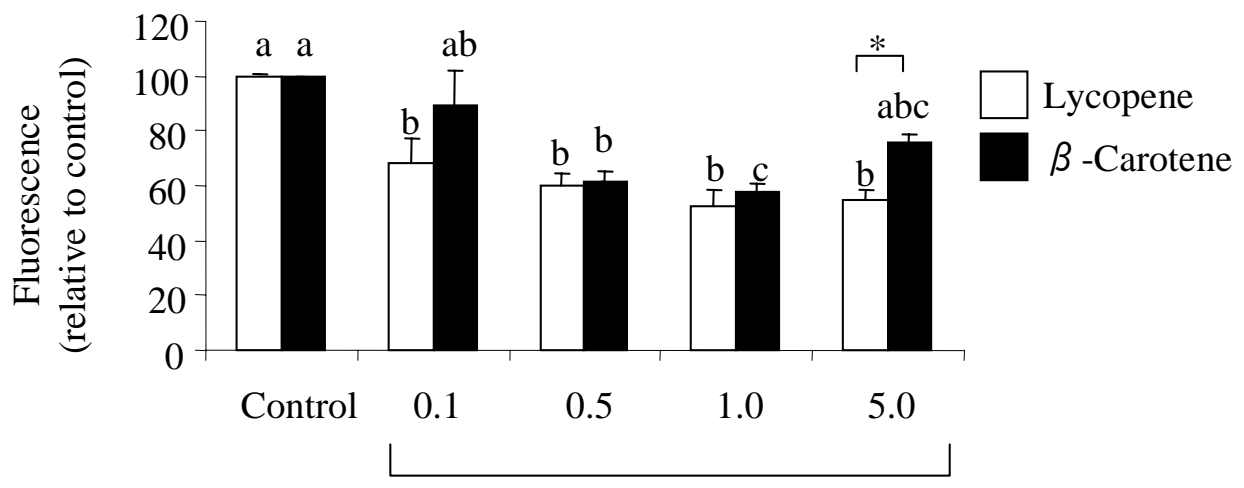

Carotenoid concentration ( $\mu \mathrm{M}$ ) 